\title{
Anemia, hypoxia and hypercapnia thresholds. Lessons from physiolog- ical limits in critically ill patients
}

$\mathrm{T}$ HE appropriate ranges for targeting physiological variables such as $\mathrm{PaO}_{2}, \mathrm{PaCO}_{2}$, or hemoglobin in the critically ill are unclear. Traditionally, practitioners have assumed that the normal ranges for healthy people are appropriate targets, or sometimes, that where vital variables such as hemoglobin are concerned, that a principal of 'more is better' may apply. Several randomized clinical studies have been completed suggesting that arbitrarily targeting given ranges is frequently inappropriate, resulting in worsened outcome in some cases. Because explanations, underlying mechanisms, and outcome studies are emerging, it seems that we need to learn progressively more about appropriate targets in the critically ill. It is possible that optimum ranges may be far more 'borderline' than previously thought.

\section{Goals of treatment in the critically ill}

The long-term goals of patient care for critically patients in ICUs are clear: to provide the greatest chances of survival with the best quality of life to all of our patients. This is easy to state, and is laudable in itself. However, because of the extreme heterogeneity associated with critically ill patient populations, it is extremely difficult for an intensivist to recognize when the best attainable outcome has been reached. In fact, it is even difficult to identify when meaningful outcome differences occur among prospectively studied groups of ICU patients.

\section{Choosing treatment goals}

There are four key issues of relevance here. First, while death or survival is deferred except in the most extreme situations, the clinician gets immediate feedback from physiological variables available at the bedside: arterial blood pressure, arterial blood gasses etc. The clinician feels -and we are all trained more or less this way- that he/she should react to these short or intermediate term alterations, and that parameter alterations that deviate from the norms in healthy population should be reversed. Second, if prognostic scoring systems are used as surrogate measures of survival, the problem is extended. These systems involve a collection of physiological variables, lumped together in a mathematical context, to yield an index of probability of outcome. Alteration of physiologic parameter can definitely alter -or, 'improve'- a given rating of severity of illness at a specific time. Of course, this may have no impact on the underlying illness, or on the specific event resulting in death or other outcome. Therefore, treating a patient towards a better illness severity rating may not be an appropriate goal. Third, whatever the overall effect of 'normalizing' a given physiologic variable or of 'improving' a prognostic score, intensivists [as is the case with almost all physicians] must remain cognizant of the cost-benefit issues related to such support. For instance, they must balance the likely benefits [frequently unknown] of elevating the hemoglobin concentration, against the likely harm [also frequently unknown] associated with achieving that elevation in hemoglobin. Fourth, when we plan to 'correct' [or worse, 'supernormalize'], say a 'low' hemoglobin in a critically ill patient, we assume that even if there were no obvious 'cost', for example, transfusing a blood product, that the patient will necessarily be better off as a result. We simply don't have the data to make such assumptions in many critically ill patients. Furthermore, we do not know whether patients' physiological systems operate more optimally in the context of say mild anemia, when the patients are critically ill. It is conceivable that the various 'thermostats' are altered when patients are critically ill; mild alterations of some physiologic variables may be appropriate for patients when they are critically ill. In 
short, just as pharmacokinetic or pharmacodynamic parameters don't apply equally to all populations, we should not expect ICU management of patient parameters to be simple and uniform. These lessons -relating especially to drug dosing- have been learned by anesthesiologists empirically generations ago, and have been explicitly demonstrated in the last few years. We therefore need to develop 'context sensitive' means of parameter management [i.e. the ability to consider each parameter in the context of the patient and his/her illness] for critically ill patients. Fifth, independent of all of the foregoing, we frequently ignore the baseline values for the particular patient in question in relation to their current status. For example, where a patient is admitted to an ICU with a systolic blood pressures measuring $80 \mathrm{mmHg}$, a very different approach is warranted if his/her 'baseline' systolic value is 90 vs $180 \mathrm{~mm} \mathrm{Hg}$ ! Finally, recovery from critical illness and healing is associated with 'normalization' of many physiological parameters towards values observed in the healthy populations. It is not surprising, therefore, that we get encouraged when our interventions result in similar directional changes in patients' physiologic variables, but we shouldn't confuse these phenomena with actual healing.

\section{Hemoglobin}

Most of us have been taught, from medical school onwards, to keep patients 'topped up' to hemoglobin values of at least $100 \mathrm{mg} \cdot \mathrm{L}^{-1}$ [hematocrit values of least $30 \%$ ], because we were led to believe, or in some cases explicitly taught, that such values were associated with optimal global and local delivery of $\mathrm{O}_{2}$. We were further taught that values less than these were associated with a variety of unfavourable outcomes such as poor wound healing, myocardial ischemia, poor splanchnic oxygenation, or other less specific but no more accurate - surrogate markers of bad clinical outcome.

The major force behind questioning the utility of a liberal approach to administering blood product transfusions was driven not by a lack of demonstrable efficacy [although there were no prospective randomized data supporting such a practice], but rather by a clearcut and readily explicable incidence of adverse effects. The impetus for such reappraisal came from class action law suites, the lay press and public inquiries not necessarily from scientific evidence of lack of beneficial effect. Our practices were associated with direct patient harm, as evidenced by scandals - on a global basis - involving transmission of HIV and hepatitis C. Subsequent research has demonstrated not only the potential for outright harm on the basis of transmis- sion of infectious - and sometimes lethal - diseases, but on the swing side, it seems clear that in dialysis patients and in ICU patients at least, transfusion for 'mild' anemia has no physiological benefit that would make the risk of transfusion associated illness a worthwhile gamble. Conversely, while the many available data are confusing, the best available data are clear: transfusion $p s$ tolerance of mild anemia is associated with worsened outcome in terms of physiologic measures and survival. ${ }^{1}$ Transfusion is not just 'not good' for critically ill patients; even if they dodge transfusion associated microbes, transfusion is frankly harmful, and it doesn't achieve the intended aims! Ironically, it was in the era of 'safe' transfusion [the post 1980s] safe, that is, in the sense of those transmissible illnesses that have thus far been characterized have largely been eliminated from the donor pool - that the studies of the of administration of blood have been shown to have adverse physiological effects. ${ }^{1-4}$ Adverse immunological effects and HIV/hepatitis aside, transfusion does bad things to critically ill patients. Some of these adverse effects include impairment of splanchnic microcirculation, retardation of global oxygen consumption [as opposed to incorrectly calculated $\mathrm{VO}_{2}$, using the PA catheter], and activation of transfused white cell-derived cytokines. There are a variety of explanations for most of these effects, but the attempts at explanations may cause us to miss the real point; arbitrary thresholds based on decades old transfusion practices or unsubstantiated physiological principles, are not useful guides to the clinical care of ICU patients. In fact, the natural direction of the patients' hemoglobin - save for active bleeding or primary hematological disorders - may reflect the optimum level of hemoglobin, just as may be the case for patients with chronic renal failure. ${ }^{5}$ We would never have learned these vital facts about transfusion physiology - facts that have enabled us to alter our traditional strategies and improve patient outcome without exploring the boundaries surrounding the thresholds for transfusion in the critically ill.

\section{Cardiovascular dynamics}

Many generations of physicians have assumed that frank shock -insufficient blood pressure to perfuse systemic organs and tissues adequately - requires immediate and appropriate therapy. Few authorities have seriously questioned this practice of striving to provide sufficient delivery of $\mathrm{O}_{2}$ to satisfy specific organ requirements. In fact, many individuals have extended this 'basic tenet' of acute medical care, and proposed that 'where a little is good, a lot must be better'. This basic concept, in addition to the erroneous assump- 
tion that global $\mathrm{O}_{2}$ demand and supply are linked at high levels of $\mathrm{O}_{2}$ delivery, led to the practice of supranormal $\mathrm{O}_{2}$ delivery. That practice, involving transfusion of red blood cells, administration of high volumes of intravenous fluids and application of high does of inotropes, was applied to many patients in many ICUs - especially in North America - for several years. Although such practices were encouraged by earlier retrospective studies or prospective studies where positive outcomes were observed only after subgroup analysis; ${ }^{6,7}$ correctly performed prospective randomized clinical trials have demonstrated either no benefit $^{8}$ or frank harm ${ }^{9}$ resulting from such an approach. Little attempt had been made to clarify dose response profiles for systemic organ function in the context of increasing, or decreasing levels of 'physiologic' support. Therefore, clinicians and investigators really had no clear idea where the outcome - or even organ function - thresholds lay in the context of such intervention in the critically ill.

\section{Intravascular volume status}

In terms of the oxygen delivery spectrum, the opposite end to the supranormal $\mathrm{DO}_{2}$ approach is frank underresuscitation. In the context of a patient who is hypotensive following penetrating torso injuries, it is highly unlikely that anyone practicing 'contemporary medicine' would remotely choose any course other than one that included aggressive replacement of intravascular volume as a primary and immediate goal. In fact, by contemporary standards, the absence of such an approach would in all likelihood constitute a departure from the accepted standard of care. Inherent in such an assumption, however, is that this approach results in improved patient outcome. Despite the above considerations, Bickell and colleagues reasoned that delaying aggressive replacement of intravascular volume in such trauma victims until arrival in the operating room might actually result in improved outcome. ${ }^{10} \mathrm{~A}$ putative rationale for such a belief might include a fear of potentiating ongoing blood loss and/or delaying definitive therapy. However, there could be other unknown factors. That this study was conducted is startling enough; the actual results were more so! Of the 598 patients randomized in the study, the survival was $70 \%$ in the delayed resuscitation group ps $62 \%$ in the conventional [early, aggressive resuscitation] group, and the differences were statistically significant. Furthermore, in the 'delayed' group, duration of hospital stay was shorter. The study does not suggest that resuscitation is a bad thing, nor does it suggest that patients should not be resuscitated. Instead, it suggests that patients' thresholds with respect to timing of resuscitation and their toler- ance of modest post-traumatic hypovolemic hypotension is quite different from that anticipated on the basis of our clinically long-held simplistic rules of thumb.

\section{Arterial oxygen tension}

In premature infants, the knowledge that elevated $\mathrm{FIO}_{2}$ contributed to retinopathy of prematurityll formerly known as retrolental fibroplasia, was the driving impetus behind exploration of - and tolerance for- lower levels of $\mathrm{PaO}_{2}$ than were previously recommended. This management approach has been made easier by the clinical availability of the oxygen electrode initially to permit rapid assessment of $\mathrm{PaO}_{2}{ }^{12}$, and subsequently by the widespread use of digital pulse oximetry permitting the on-line assessment of arterial hemoglobin saturation. ${ }^{13}$ Before the current focus - in adult critical care medicine - on ventilator associated lung injury, it was increasingly recognized that bronchopulmonary dysplasia - long-term lung dysfunction occurring in childhood survivors of prematurity - seemed to be associated with mechanical ventilation and elevated levels of inspired oxygen. ${ }^{14}$ Aside therefore, from the tolerance of neonates to lower [i.e. $60-90 \mathrm{mmHg}$ ] than 'normal' levels of $\mathrm{PaO}_{2}$ [approximately $90-100 \mathrm{mmHg}$ in healthy neonates breathing room air], intensivists have recognized that there is a direct cost to the infant associated with attempting to raise the $\mathrm{PaO}_{2}$.

In adults, the situation is probably similar, but the clinical presentation of adverse effects is different. While the value of $\mathrm{PaO}_{2}$ in healthy adults is known, the optimal value for critically ill adults is not. Although values for the lowest tolerable $\mathrm{PaO}_{2}$ have been proposed on theoretical grounds [in the range of $36 \mathrm{~mm} \mathrm{Hg}$ ] -based on blood oxygen carrying capacity, tissue consumption and predicted $\mathrm{O}_{2}$ extraction ratios- these have for obvious reasons not been tested in humans. Furthermore, much lower values [20-30 $\mathrm{mm} \mathrm{Hg}$ ] can be tolerated in individuals who have had the opportunity to acclimatize to hypoxic conditions. ${ }^{12}$ Many factors can confound these calculations. For instance, oxygen consumption can be differentially altered in many tissues or organs [e.g. B-blockade reduces myocardial oxygen consumption; sedation reduces cerebral oxygen consumption, etc.]. Organ blood flow can be linked to metabolic rate, or may be limited for other reasons. In addition, tissue oxygen delivery and microvascular control is highly abnormal in patients with sepsis ${ }^{15}$ or systemic inflammatory responses, making assumptions about thresholds or safety seem more speculative. Finally, our currently available means of detecting or quantifying the extent of tissue hypoxia e.g. gastric mucosal tonometry, or 
global indices including lactate or estimated global $\mathrm{VO}_{2}$, have not been clinically validated in terms of usefully guiding clinical care. ${ }^{16} \mathrm{~A}$ nationwide survey of Canadian intensivists revealed a wide range acceptable levels of $\mathrm{PaO}_{2}$ in critically ill patients. ${ }^{17}$ However, experienced intensivists accept predictably altered maximal and minimal $\mathrm{FIO}_{2}$ depending on the current arterial $\mathrm{O}_{2}$ tension. ${ }^{17}$

The adverse consequences resulting from efforts to elevate $\mathrm{PaO}_{2}$ need to be outlined, and have been described in some detail. ${ }^{18}$ Potential adverse systemic effects from elevated $\mathrm{FIO}_{2}$ include decreases in cardiac output and increases in systemic vascular resistance ${ }^{19}$ and possibly by a reduction in systemic global $\mathrm{VO}_{2}{ }^{20}$ The somewhat better recognized pulmonary effects associated with elevated inspired $\mathrm{O}_{2}$ concentration include progressive reduction in spirometric performance, ${ }^{21}$ progressive increases in interstitial fibrosis, ${ }^{22}$ upregulated white cell mediator production, ${ }^{23}$ and intraoperatively - significant worsening of ventilation/perfusion mismatching due to microatelactasis. ${ }^{24}$ In terms of outcome, it should be noted that resuscitation from cardiac arrest in a canine model while ventilating with hyperoxic $v s$ normoxic gas, was associated with a worse neurological outcome. ${ }^{25}$ Such effects may be due to the increased propensity for systemic free radical production that has been associated with hyperoxia. ${ }^{26,27}$ The adverse effects of mechanical ventilation are far better described in animal models, and the exact relevance of these models to patients with critical illnesses is far from clear. Nevertheless, several authorities have identified mechanical ventilation as a potentially important factor in the development of adverse outcome in critically ill patients. The specific effects of mechanical ventilation have been reviewed in detail, ${ }^{28}$ and include interstitial fibrosis, margination of inflammatory cell, and up-regulation of inflammatory cytokines.

Thus, the key discussion is not the simple - but elusive - question: what is the lowest safe $\mathrm{PaO}_{2}$ ? Instead the focus is on [a] the safest trade-off between the harmful effects of low $\mathrm{O}_{2}$ tension $p s$ [b] the putative benefits of raising that $\mathrm{PaO}_{2}$ vs $[\mathrm{c}]$ the potential iatrogenicity associated with attempts to achieve that elevation in $\mathrm{PaO}_{2} \cdot{ }^{18}$ Given the uncertainty surrounding the issue of optimal oxygenation in the critically ill, studies - currently underway - exploring the relative effects of reducing requirements $\left[\mathrm{FIO}_{2}\right.$, PEEP etc.] ps differential effects on tissue oxygenation for different yet clinically acceptable target $\mathrm{PaO}_{2}$ levels, should point towards the direction of 'best $\mathrm{PO}_{2}$ ' in the critically ill. Such results, will remain to be verified in large-scale outcome studies.

\section{Arterial carbon dioxide tension}

Elevated levels of arterial $\mathrm{CO}_{2}$ have been progressively tolerated by clinicians - and their patients - in intensive care units ${ }^{29}$ We used to target 'normal' levels of $\mathrm{PaCO}_{2}$ [i.e. $38-42 \mathrm{~mm} \mathrm{Hg}$ ] in mechanically ventilated patients with respiratory failure. Clearly, it is inappropriate for patients with long established chronic $\mathrm{CO}_{2}$ retention [oxygen induced hypercapnia], to have $\mathrm{PaCO}_{2}$ tensions targeted to the 'normal' range, or worse, to ranges lower than that. Some evidence suggests that ventilatory strategies that result in the development of permissive hypercapnia, are associated with improved outcome in adults with ARDS. ${ }^{30-32}$ This follows the original description of reduced ventilator induced lung injury while permitting elevated $\mathrm{CO}_{2}$ tension - in neonates with persistent fetal circulation. ${ }^{33}$ This approach was associated with dramatic improvements in survival and frequency of respiratory and CNS outcome. ${ }^{33}$

Furthermore, evidence is evolving suggesting that acidosis - metabolic and respiratory - may be protective against ongoing production of further organic acids. ${ }^{34}$ In fact we have shown in our laboratory that respiratory acidosis can exert a markedly protective effect on several models of acute lung injury. ${ }^{35}$ Therefore, by exploring the appropriate thresholds for tolerance of hypercapnia, in a 'permissive' sense, we have learned that hypercapnia is not necessarily something bad, or even harmless; rather it may exert a protective influence on the pathogenesis of acute organ injury. ${ }^{35}$

\section{Summary}

Physiological alterations occur in the critical care medicine, and reflect illness. Rendering patients physiologic parameters in the range that is normal for the population is not necessarily good; it may be frankly harmful. We do not currently possess outcome-based tools that allow us to titrate physiological parameters and ensure improved outcome. It is highly unlikely that our practice will evolve to inducing anemia, hyperthermia, hypoxemia, hypercapnia and hypotension in our critically ill patients! However, evolving knowledge of the appropriate thresholds for these parameters in critically ill patients, in addition to greater understanding of the potential iatrogenic illness associated with parameter 'normalization', could lead to provision of enhanced patient care. In the coming years it is possible that we will redefine the 'normal' range for common clinical and laboratory values relating to the critically ill. We may switch to 'context sensitive' interpretation of parameters of illness, and manage critically ill patients accordingly.

\section{Acknowledgment}

The comments of Dr. J.G. Laffey are appreciated. 


\section{References}

1 Hebert $P C$, Wells $G$, Blajchman $M$, et al. Transfusion practice in the critically ill. N Engl J Med 1999; 340: 409-17.

2 Hebert PC, Wells G, Tweeddale $M$, et al. Does transfusion practice affect mortality in critically ill patients? Am J Resp Crit Care Med 1998; 155: 1618-23.

3 Hebert PC, Wells GA, Marshall J, et al. Transfusion requirements in critical care: a pilot study. JAMA 1995; 273: 1439-44.

4 Marik PE, Sibbald WJ. Effect of stored-blood transfusion on oxygen delivery in patients with sepsis. JAMA 1993; 269: 3024-9.

5 Besarab A, Bolton WK, Browne JK, et al. The effects of normal as compared with low hematocrit vcalues in patients with cardiac disease who are receiving hemodialysis and epoetin. N Engl J Med 1998; 339: 584-90.

6 Tuchschmidt J, Fried J, Astiz M, Rackow E. Elevation of cardiac output and oxygen delivery improves outcome in septic shock. Chest 1992; 102: 216-20.

7 Boyd O, Grounds RM, Bennett ED. A randomized clinical trial of the effect of deliberate perioperative increase of oxygen delivery on mortality in high-risk surgical patients. JAMA 1993; 270: 2699-707.

8 Gattinoni L, Brazzi L, Pelosi P, et al. A trial of goal-orientated hemodynamic therapy in critically ill patients.

N Engl J Med 1995; 333: 1025-32.

9 Hayes $M A$, Timmins AC, Yau EHS, Palazzo M, Hinds $C J$, Watson $D$. Elevation of systemic oxygen delivery in the treatment of critically ill patients. $N$ Engl J Med 1994; 330: 1717-22.

10 Bickell $W H$, Wall $M J$, Pepe PE, et al. Immediate versus delayed fluid resuscitation for hypotensive patients with pentrating torso injuries. N Engl J Med 1994; 331: 1105-9.

11 Bossi E, Koerner $F$. Retinopathy of prematurity (review). Intensive Care Med 1995; 21: 241-6.

12 Nunn JF. Applied Respiratory Physiology. London: Butterworths, 1987.

13 Fairley $\mathrm{HB}$. Changing perspectives in monitoring oxygenation. Anesthesiology 1989; 70: 2-4.

14 Abman SH, Grootbius JR. Pathophysiology and treatment of bronchopulmonary dysplasia. Current issues. Pediatric Clinics of North America 1994; 41: 277-315.

15 Hotcbkiss RS, Karl IE. Reevaluation of the role of cellular hypoxia and bioenergetic failure in sepsis [review]. JAMA 1992; 267: 1503-10.

16 Third European consensus conference in Intensive Care Medicine. Tissue Hypoxia. How to detect, how to correct, how to prevent. Am J Resp Crit Care Med 1996; 154: 1573-8.

17 Kavanagh BP, Ngo C. Attitudes and beliefs concerning oxygen use in ventilated patients in the ICU - A
Canada-wide survey. Can J Anaesth 1997; 44: A3.

18 Kavanagh BP. Goals and concerns for oxygenation in acute respiratory distress syndrome. Curr Opinion Crit Care 1998; 4: 16-20.

19 Lodato $R$. Decreased $\mathrm{O}_{2}$ consumption and cardiac output during normobaric hyperoxia. J Appl Physiol 1989; 67: 1551-9.

20 Reinhart $K$, Bloos $F$, Konig F, Bredel D, Hanneman $L$. Reversible decrease of oxygen consumption by hyperoxia. Chest 1991; 99: 690-4.

21 Caldwell PRB, Lee WK, Schildkraut HS, Archibald ER. Changes in lung volume, diffusing capacity, and blood gasses in men breathing oxygen. J Appl Physiol 1966; 21: 1477-83.

22 Crapo JD, Hayatdapoudi G, Knapp MJ, Fracica PJ, Wolfe WG, Piantadosi CA. Progressive alveolar septal injury in primates exposed to $60 \%$ oxygen for 14 days. Am J Physiol 1994; 267: L797-806.

23 Griffith DE, Garcia JG, James $H L$, Callahan KS, Iriana $S$, Holiday D. Hyperoxic exposure in humans. Effects of 50 percent oxygen on alveolar macrophage leukotriene B4 synthesis. Chest 1992; 101: 392-7.

24 Rothen HU, Sporre B, Engberg G, Wegenius G, Reber $A$, Hedenstierna $G$. Prevention of atelectasis during general anaesthesia. Lancet $1995 ; 345: 1387-91$.

25 Zwemer CF, Whitesall SE, D'Alecy LG. Cardiopulmonary-cerebral resuscitation with $100 \%$ oxygen exacerbates neurological dysfunction following nine minutes of normothermic cardiac arrest in dogs. Resuscitation 1994; 27: 159-70.

26 Tusa $T$, Crapo JD, Freeman BA. Hyperoxia enhances lung and liver nuclear superoxide generation.

Biochimica et Biophysica Acta 1984; 798: 167-74.

27 Yusa T, Beckman JS, Crapo JD, Freeman BA. Hyperoxia increases $\mathrm{H}_{2} \mathrm{O}_{2}$ production by brain in vivo. J Appl Physiol 1987; 63: 353-8.

28 Parker JC, Hernandez LA, Peevy KJ. Mechanisms of ventilator-induced lung injury (review). Crit Care Med 1993; 21 : 131-43.

29 Feibl F, Perret C. Permissive hypercapnia. How permissive should we be? Am J Resp Crit Care Med 1994; 150: 1722-37.

30 Amato MB, Barbas CS, Medeiros DM, et al. Beneficial effects of the "open lung approach" with low distend ing pressures in acute respiratory distress syndrome. A prospective randomized study on mechanical ventilation. Am J Resp Crit Care Med 1995; 152: 1835-46.

31 Amato MB, Barbas CS, Medeiros DM, et al. Effect of a protective-ventilation strategy on mortality in the acute respiratory distress syndrome. N Engl J Med 1998; 338: 347-54.

32 Hickling KG, Henderson SJ, Jackson R. Low mortality associated with low volume pressure limited ventilation 
with permissive hypercapnia in severe adult respiratory distress syndrome. Intensive Care Med 1990; 16: 372-7.

33 Wung JT, James LS, Kilcheosky E, James E.

Management of infants with severe respiratory failure and persisence of the fetal circulation, without hyperventilation. Pediatrics 1985; 76: 488-94.

34 Hood VL, Tanen $R L$. Protection of acid-base balance by $\mathrm{pH}$ regulation of acid production (review). $\mathrm{N}$ Engl J Med 1998; 339: 819-26.

35 Shibata $K$, Cregg $N$, Engelberts $D$, Takeuchi $A$, Fedorko $L$, Kavanagh BP. Hypercapnic acidosis may attenuate acute lung injury by inhibition of endogenous xanthine oxidase. Am J Resp Crit Care Med 1998; 158: 1578-84. 


\section{Les seuils d'anémie, d'hypoxie et d'hypercap- nie. Leçons à tirer des limites physiologiques chez les patients grave- ment malades}

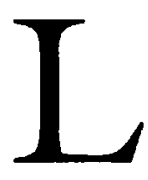

'INTERVALLE à établir quand on veut cibler les variables physiologiques comme la $\mathrm{PaO}_{2}$, la $\mathrm{PaCO}_{2}$, ou l'hémoglobine, chez les grands malades n'est pas clair. Les médecins ont supposé traditionnellement que les valeurs normales pour les gens en santé étaient les cibles à utiliser, ou quelquefois, quand des variables vitales comme l'hémoglobine sont en jeu, qu'un principe du «plus, c'est mieux» peut s'appliquer. Certaines études cliniques randomisées avancent que de cibler des limites de variables données est souvent inapproprié, ce qui aggrave la situation dans certains cas. Avec. la parution d'études explicatives, soustendant des mécanismes, et d'études de résultats, il semble bien que nous allons progressivement en apprendre plus sur les cibles convenables à utiliser avec les grands malades. Il est possible que l'intervalle optimale soit beaucoup plus «limitée qu'on l'a d'abort cru.

\section{Objectifs de traitement des grands malades}

Les objectifs à long terme de soins aux patients gravement malades de l'USI sont clairs: accorder les meilleures chances de survie et la meilleure qualité de vie à tous. Cela est facile à dire et louable en soi. Cependant, à cause de la très grande hétérogénéité associée à la population des grands malades, il est extrêmement difficile pour un intensiviste de savoir quand les meilleurs résultats possibles ont été atteints. En fait, il est même difficile d'identifier quand des différences significatives de résultats se présentent entre les groupes d'études prospectives auxquelles participent des patients de l'USI.

\section{Le choix des objectifs de traitement}

Quatre sujets clé sont pertinents ici. Le premier, quand la mort ou la survie sont différées, sauf dans les situations les plus extrêmes, le clinicien obtient une réac- tion immédiate des variables physiologiques au moyen des appareils disponibles au chevet du patient: tension artérielle, gaz artériels, etc. Le clinicien croit, et nous avons tous été formés plus ou moins en ce sens, qu'il doit réagir à ces changements de durée brève ou intermédiaire et que les paramètres qui s'éloignent de la normale de la population en santé devraient être renversés. Le deuxième, si des systèmes de cotation du pronostic sont utilisés à la place des mesures de survie, le problème s'accentue. Ces systèmes comportent une collection de variables physiologiques, considérées en bloc dans un contexte mathématique, pour fournir un index de probabilité de résultat. La modification d'un paramètre physiologique peut certainement changer, ou "améliorer", une estimation donnée de la sévérité de la maladie à un moment précis. Bien sûr, cela peut ne pas avoir d'impact sur la maladie sous-jacente, ou sur l'incident spécifique à l'origine du décès ou d'une autre issue. Par conséquent, traiter un patient en visant un meilleur taux à l'échelle de la sévérité de la maladie peut ne pas être un objectif convenable. Le troisième, quel que soit l'effet global de «normalisation» d'une variable physiologique donnée ou de l'«amélioration" d'un score de pronostic, les intensivistes, comme c'est le cas avec la plupart des médecins, doivent demeurer conscients des rapports coût-bénéfices liés à une telle assistance. Par exemple, ils doivent mettre en parallèle les avantages probables, souvent inconnus, de l'élévation de la concentration d'hémoglobinè, et les inconvénients possibles, souvent inconnus aussi, associés à cette élévation de l'hémoglobine. Le quatrième, lorsque nous planifions de "corriger", ou pire, de "supernormaliser», par exemple un faible taux d'hémoglobine chez un grand malade, nous supposons que même s'il 'n'y a pas de coût évident, de transfusion d'un produit sanguin par exemple, que le patient sera nécessairement mieux par la suite. Nous n'avons tout 
simplement pas les données requises pour faire de telles suppositions dans de nombreux cas de patients très malades. De plus, nous ne savons pas si les systèmes physiologiques du patient fonctionnent mieux dans le contexte d'une anémie légère par exemple, quand le patient est gravement malade. On peut imaginer que les différents "thermostats" sont alors modifiés; de légères modifications de certaines variables physiologiques peuvent être appropriées chez ces patients. Bref, comme les paramètres pharmacocinétiques et pharmacodynamiques ne s'appliquent pas également à toutes les populations, nous ne pouvons nous attendre que la prise en charge des paramètres des patients de l'USI soit simple et uniforme. Ces leçons, récisément relatives au dosage des médicaments, ont été apprises par les anesthésiologistes de façon empirique, il y a de cela des générations, et ont été explicitemente démontrées au cours des dernières années. Nous devons alors élaborer une prise en charge des moyennes «contextuelles» des paramètres, c'est-à-dire la capacité de considérer chaque paramètre dans le contexte du patient et de sa maladie. Le cinquième, indépendamment de tout ce qui précède, souvent nous faisons fi des valeurs de base en relation avec l'état actuel d'un patient en particulier. Par exemple, si un patient est admis à l'USI et présente une tension artérielle systolique de $80 \mathrm{mmHg}$, un mode d'action très différent sera nécessaire selon que la valeur systolique de base est de 90 ps $180 \mathrm{mmHg}$ ! Finalement, la récupération d'une maladie grave et la guérison sont associées à la "normalisation» de nombreux paramètres physiologiques en regard des valeurs observées chez les populations en santé. Ce n'est pas surprenant alors, que nous soyons encouragés quand nos interventions résultent en changements des variables physiologiques des patients dans ce sens, mais nous ne devrions pas confondre ce phénomène avec la guérison effective.

\section{Hémoglobine}

Depuis l'école de médecine qu'on nous enseigne à garder les valeurs de l'émoglobine des patients à un "plein" niveau d'au moins $100 \mathrm{mg} \cdot \mathrm{L}^{-1}$, les valeurs de l'hématocrite de moins de $30 \%$, parce que nous avons été amenés à croire, ou dans certains cas on nous a explicitement enseigné, que de telles valeurs étaient associées à la livraison optimale globale d' $\mathrm{O}_{2}$ local. On nous a ensuite appris que les valeurs plus basses que celles-là étaient associées à une variété de complications, comme la mauvaise cicatrisation, l'ischémie myocardique, l'oxygénation splanchnique insuffisante, ou à d'autres marqueurs substituts moins spécifiques mais pas plus justes - de résultats cliniques pauvres.
La raison principale de la remise en question de l'utilité d'une méthode libérale d'administration des transfusions sanguines a été influencée non pas par un manque d'efficacité démontrable, bien qu'il n'existe pas de données randomisées et prospectives pour appuyer une telle pratique, mais plutôt par une incidence nettement et facilement explicable d'effets secondaires. L'impulsion qui a mené à une telle réévaluation est venue des recours collectifs en justice, de la couverture de la presse et des enquêtes publiques, et non pas nécessairement de l'évidence scientifique d'un manque d'effet bénéfique. Nos pratiques ont été associés à un tort direct fait au patient, comme l'ont mis en évidence les scandales - sur une base générale - incluant la transmission du VIH et de l'hépatite C. Des recherches ultérieures ont démontré non seulement le potentiel de danger réel, basé sur la transmission de maladies infectieuses, et parfois mortelles, mais d'un autre côté, il semble clair que chez les patients dialysés et chez ceux de l'USI au moins, la transfusion visant à corriger une «légère" anémie n'apporte pas de bénéfice physiologique qui pourrait faire du risque de transfusion associée à la maladie un jeu qui en vaut la chandelle. Réciproquement, tandis que les données les plus disponibles sont confondantes, les meilleures données disponibles sont claires: la transfusion vs la tolérance à une légère anémie est associée à l'aggravation des complications en termes de mesures physiologiques et de survie. ' La transfusion n'est pas seulement "néfaste» aux patients gravement malades; même si on évite les microbes associés à la transfusion, elle est franchement nuisible, et elle n'atteint pas les buts visés. Ironiquement, c'est à l'époque des transfusions «sûres», après les années 1980, sûres au sens où ces maladies transmissibles ont été depuis lors caractérisées et ont été grandement éliminées du pool des donneurs, que des études ont montré que l'administration du sang avait des effets physiologiques indésirables. ${ }^{1-4}$ Les effets secondaires immunologiques et les VIH/hépatite mis à part, la transfusion nuit aux grands malades. Certains effets secondaires incluent des troubles de la microcirculation splanchnique, un retard de consommation d'oxygène totale - en opposition au calcul incorrect du $\mathrm{VO}_{2}$, à l'aide d'un cathéter PA - et l'activation de cytokines dérivées des leucocytes. On peut expliquer la plupart de ces effets de bien des manières, mais les tentatives d'explication peuvent nous faire oublier le point crucial; des seuils basés sur l'arbitraire de décennies d'anciennes pratiques de transfusion ou sur des principes physiologiques non corroborés, ne sont pas des guides utiles aux soins clinques à l'USI. De fait, le contrôle normal de l'hémoglobine du patient - sauf pour des saignements actifs ou des désordres héma- 
tologiques primaires - peut refléter le niveau optimal de l'hémoglobine, tout comme ce peut être le cas pour les patients atteints d'insuffisance rénale chronique. ${ }^{5}$ Nous n'aurions jamais appris ces faits d'importance vitale au sujet de la physiologie de la transfusion - faits qui nous ont aidé à modifier nos stratégies traditionnelles et à améliorer l'évolution du patient - si nous n'avions pas exploré les frontières entourant les seuils des paramètres de transfusion auprès des grands malades.

\section{Dynamique cardio-vasculaire}

De nombreuses générations de médecins ont présumé que le choc d'évidence clinique - tension artérielle insuffisante pour perfuser les organes et les tissus de façon adéquate - nécessitait une thérapie immédiate et appropriée. Peu d'autorités ont sérieusement remis en question le fait de s'évertuer à fournir une livraison suffisante d' $\mathrm{O}_{2}$ pour satisfaire aux besoins d'organes spécifiques. Nombreux sont ceux, en fait, qui ont étendu ce "principe de base» aux soins médicaux aigus et qui ont proposé que «si un peu c'est bon, beaucoup ce doit être meilleur». Ce concept de base, en plus de la supposition erronée qui veut que l'apport et la demande d' $\mathrm{O}_{2}$ total soient liés à des hauts niveaux de livraison $\mathrm{d}^{\prime} \mathrm{O}_{2}$, a conduit à la pratique de livraison supranormale d'O $\mathrm{O}_{2}$. Cette pratique, impliquant la transfusion de globules rouges, l'administration de volumes élevés de liquides intraveineux et l'application de fortes doses d'inotropes, a été appliquée à de nombreux patients dans de nombreuses USI - surtout en Amérique du Nord - pendant quelques années. Bien que de telles pratiques aient été encouragées par des études rétrospectives ou prospectives antérieures où des résultats positifs ont été observés à la suite de l'analyse de sous-groupes, ${ }^{6,7}$ des essais cliniques prospectifs randomisés et correctement réalisés n'ont démontré ni bénéfice, ${ }^{8}$ ni dommage réel ${ }^{9}$ résultant d'une démarche semblable. On avait peu tenté de clarifié les profils de réponses dépendant de la dose pour la fonction organique générale dans les situations d'augmentation ou de diminution des niveaux d'assistance «physiologique». En conséquence, les cliniciens et les chercheurs ne savent pas vraiment où se situent les seuils des résultats - ou même de la fonction organique - dans le contexte de telles interventions auprès des grands malades.

\section{Etat du volume intravasculaire}

Concernant le champ d'efficacité de la livraison d'oxygène, l'opposé à la méthode de livraison supranormale d' $\mathrm{O}_{2}$ se situe juste en-dessous de la réanimation. Dans la situation d'un patient hypotendu à la suite de plaies par pénétration thoracique, il est fort peu probable que quiconque pratiquant la «médecine contemporaine" ne choisisse une autre avenue que celle qui comprend le remplacement énergique du volume intravasculaire comme but premier et immédiat. En fait, selon les standards actuels, l'absence d'une telle démarche constituerait de toute évidence une dérogation au standard de soin. Il est toutefois inhérent à cette déclaration que cette façon de procéder améliore l'évolution du patient. En dépit des affirmations précitées, Bickell et ses collègues ont estimé que de retarder le remplacement actif du volume intravasculaire chez les victimes de traumatisme jusqu'à l'arrivée en salle d'opération pouvait en fait améliorer l'issue du traitement. ${ }^{10}$ Un exposé logique possible d'un tel raisonnement inclurait la crainte que la perte sanguine n'évolue et/ou ne retarde une thérapie décisive. Cependant, il pourrait y avoir d'autres facteurs inconnus. Que cette étude ait été faite, c'est déjà assez surprenant, les résultats effectifs le sont davantage! Des 598 patients répartis au hasard lors de l'étude, la survie a été de $70 \%$ dans le groupe où on a retardé la réanimation vs $62 \%$ dans le groupe où on a utilisé la démarche habituelle, la réanimantion précoce et énergique, et les différences intergroupes étaient significatives au plan statistique. De plus, dans le groupe «retardé», le séjour hospitalier a été plus court. L'étude ne conclut pas que la réanimation est une mauvaise chose, ni que les patients ne devraient pas être réanimés. Elle propose plutôt que les seuils physiologiques des patients en regard du moment de la réanimation et de leur tolérance à la faible hypotension hypovolémique post-traumatique sont assez différents de ce à quoi on s'attendait en se basant sur nos règles générales et simplistes connues depuis longtemps.

\section{Tension artérielle d'oxygène}

Chez les enfants prématurés, la découverte qu'une $\mathrm{FIO}_{2}$ élevée contribuait à la rétinopathie ${ }^{11}$, connue auparavant sous le nom de fibroplasie rétrolentale, a conduit à l'exploration - et à la tolérance - de niveaux plus bas de $\mathrm{PaO}_{2}$ que ceux qui étaient recommandés précédemment. Cette ligne de conduite a été facilitée par la disponibilité clinique d'électode à oxygène pour permettre d'abord une évaluation rapide de $\mathrm{la}^{\mathrm{PaO}_{2}}{ }^{12}$, et par la suite, grâce à l'usage répandu de l'oximétrie digitale pulsée, l'évaluation en ligne de la saturation artérielle d'hémoglobine. ${ }^{13}$ Avant l'intérêt actuel, en médecine des soins intensifs chez les adultes, pour les lésions pulmonaires associées à la ventilation, on reconnaissait de plus en plus que la dysplasie bronchopulmonaire, un dysfonctionnement pulmonaire à long terme survenant chez les enfants qui survivent à la prématurité, semblait associée à la ventilation mécanique et à des niveaux élevés 
d'oxygène inspiré. ${ }^{14}$ En conséquence, mis à part la tolérance des nouveau-nés à des niveaux de $\mathrm{PaO}_{2}$ plus bas $(60-90 \mathrm{mmHg}$ ) que la normale (approximativement 90-100 $\mathrm{mmHg}$ chez les nouveau-nés en santé qui respirent l'air ambiant), les intensivistes ont reconnu qu'il y a des répercussions directes pour l'enfant chez qui on essait d'augmenter la $\mathrm{PaO}_{2}$.

Chez les adultes, la situation est probablement similaire, mais la présentation clinique des effets secondaires est différente. Tandis que la valeur de $\mathrm{PaO}_{2}$ est connue chez les adultes en santé, la valeur optimale chez les adultes gravement malades ne l'est pas. Même si les plus basses valeurs de $\mathrm{PaO}_{2}$ tolérables ont été proposées en théorie, selon un intervalle de $36 \mathrm{mmHg}$, basées sur la capacité du sang de transporter l'oxygène, la consommation tissulaire et la prédiction des taux d'extraction d'O $\mathrm{O}_{2}$, cela n'a pas été vérifié chez les humains pour des raisons évidentes. En outre, des valeurs beaucoup plus basses, $20-30 \mathrm{mmHg}$, peuvent être tolérées chez des individus qui ont pu s'acclimater à des conditions hypoxiques. ${ }^{12}$ De nombreux facteurs peuvent transformer ces calculs. Par exemple, la consommation d'oxygène peut être modifiée différemment dans beaucoup de tissus ou d'organes. Entre autre, les ß-bloquants réduisent la consommation myocardique d'oxygène et la sédation en réduit la cosommation cérébrale. Le débit sanguin organique peut être relié au taux métabolique ou être limité pour d'autres raisons. En plus, la livraison d'oxygène tissulaire et le contrôle microvasculaire sont fortement anormaux chez les patients atteints de septicémie ${ }^{15}$ ou de réaction inflammatoire généralisée, ce qui rend les hypothèses plus spéculatives au sujet des seuils ou de la sécurité. Enfin, les moyens dont nous disposons habituellement pour détecter ou qualifier l'étendue de l'hypoxie tissulaire, par exemple la tonométrie de la muqueuse gastrique ou les indices globaux comprenant le lactate ou le $\mathrm{VO}_{2}$ total présumé, n'ont pas été validés en clinique pour servir utilement aux soins. ${ }^{16}$ Une enquête pancanadienne des intensivistes a révélé un large éventail de niveaux acceptables de $\mathrm{PaO}_{2}$ chez les patients très malades. ${ }^{17}$ Cependant, les intensivistes d'expérience acceptent comme on pouvait le prévoir des valeurs maximales et minimales modifiées de $\mathrm{FIO}_{2}$ d'après la tension artérielle d'oxygène actuelle.

Les conséquences néfastes des efforts faits pour élever la $\mathrm{PaO}_{2}$ doivent être soulignées et on les a déjà décrites avec quelques détails. ${ }^{18}$ Les effets secondaires généraux possibles à la suite d'une élévation de $\mathrm{la}_{\mathrm{FIO}_{2}}$ comprennent des baisses de débit cardiaque général et des hausses de la résistance vasculaire générale ${ }^{19} \mathrm{et}$, probablement, par une réduction du $\mathrm{VO}_{2}$ total ${ }^{20}$ Les effets pulmonaires les mieux connus en quelque sorte, associés à des concentrations élevées d' $\mathrm{O}_{2}$ inspiré, comprennent la réduction progressive de la performance spirométrique, ${ }^{21}$ l'augmentation progressive de fibrose interstitielle, ${ }^{22}$ la production de médiateurs des leucocytes en régulation positive ${ }^{23}$ et, en période peropératoire, l'aggravation significative du décalage entre ventilation et perfusion à cause de la microatélectasie. En termes de complications, on doit noter que la réanimation après un arrêt cardiaque chez un modèle canin pendant la ventilation avec des gaz hyperoxiques $v s$ normoxiques, a été associée à des complications neurologiques plus graves. De tels résultats peuvent avoir été causés par la propension accrue de production de radicaux libres qui a été associée à l'hyperoxie. ${ }^{26,27}$ Les complications de la ventilation mécanique ont été beaucoup mieux décrits chez les modèles animaux, et la pertinence réelle de ces modèles pour les patients très malades est loin d'être claire. Néanmoins, certains chercheurs ont identifié la ventilation mécanique comme un facteur important possible dans le développement de complications chez les grands malades. Les effets spécifiques de la ventilation mécanique ont été revus en détails. ${ }^{28} \mathrm{Ce}$ sont la fibrose interstitielle, la margination des cellules inflammatoires et la régulation positive des cytokines inflammatoires.

Ainsi, l'argument clé n'est pas la simple - mais évasive - question : quel est la plus basse $\mathrm{PaO}_{2}$ sécuritaire? L'accent est plutôt mis sur a) le choix le plus sûr entre les effets nuisibles de faible tension $\mathrm{d}^{\prime} \mathrm{O}_{2}$ vs $\mathrm{b}$ ) les avantages possibles d'augmenter la $\mathrm{PaO}_{2}$ vsc) l'iatrogénicité potentielle associée aux essais d'élévation de la $\mathrm{PaO}_{2}{ }^{18}$ Étant donné l'incertitude qui entoure la question de l'oxygénation optimale chez les grands malades, les études actuellement en cours qui explorent les effets relatifs de la réduction des besoins $\left(\mathrm{FrO}_{2}, \mathrm{PEP}\right.$, etc. $)$ vs les effets différentiels sur l'oxygénation des tissus pour différents niveaux cibles de $\mathrm{PaO}_{2}$, néanmoins acceptables en clinique, doivent s'orienter vers la «meilleure $\mathrm{PO}_{2}$ » chez les grands malades. Ces résultats seront à vérifier lors de grandes séries sur les complications.

\section{Tension arterielle du gaz carbonique}

Des niveaux élevés de $\mathrm{CO}_{2}$ artériel ont été progressivement tolérés par les cliniciens et leurs patients à l'unité des soins intensifs. ${ }^{29}$ Nous avons ciblé les niveaux «normaux» de $\mathrm{PaCO}_{2}, 38-42 \mathrm{mmHg}$, chez des patients atteints d'insuffisance respiratoire sous ventilation mécanique. Il est clair que c'est inapproprié pour des patients présentant une rétention chronique de $\mathrm{CO}_{2}$ installée depuis longtemps (hypercapnic induite par l'oxygène), de cibler les tensions de $\mathrm{PaCO}_{2}$ selon des limites «normales», ou pire, selon des limites plus basses. Il y a certaines indications selon lesquelles les straté- 
gies ventilatoires qui résultent du développement de l'hypercapnie permissive sont associées à l'évolution positive chez les adultes qui sont atteints du SDRA. ${ }^{30-32}$ Cela fait suite à la description originale de la réduction de la lésion pulmonaire provoquée par la ventilation tandis qu'on permet des tension de $\mathrm{CO}_{2}$ élevées - chez les nouveau-nés présentant une circulation foetale persistante ${ }^{33}$ Cette méthode a été associée à des améliorations importantes de la survie et à la réduction des complications respiratoires et neurologiques. ${ }^{33}$

De plus, les preuves se développent suggérant que l'acidose, métabolique et respiratoire, peut être protectrice contre la production permanente d'autres acides organiques. ${ }^{34}$ En fait, nous avons montré dans notre laboratoire que l'acidose respiratoire peut exercer un effet protecteur marqué sur certains modèles de lésion pulmonaire aiguë. ${ }^{35}$ En conséquence, en explorant les seuils appropriés de tolérance de l'hypercapnie, dans le sens "permissif", nous avons appris que l'hypercapnie n'est pas nécessairement néfaste, ou même dangereuse, elle exercerait plutôt une influence protectrice sur la pathogenèse de la lésion organique aiguë. ${ }^{35}$

\section{Sommaire}

Des changements physiologiques surviennent à l'USI et reflètent la maladie. Interpréter les paramètres physiologiques des patients selon les limites qui sont normales pour la population n'est pas nécessairement bon; cela peut être franchement mauvais. Nous ne possédons pas présentement d'outils basés sur les complications qui nous permettent de doser les paramètres physiologiques et d'assurer l'amélioration des résultats thérapeutiques. Il est hautement improbable que notre pratique évolue vers l'induction de l'anémie, de l'hyperthermie, l'hypoxémie, l'hypercapnie et l'hypotension chez les patient gravement malades! Toutefois, l'évolution des connaissances sur les seuils appropriés de ces paramètres chez les grands malades, en plus d'une meilleure compréhension de la maladie iatrogénique potentielle associée à la "normalisation" des paramètres, peuvent conduire à l'amélioration des soins. Dans les années à venir, il est possible que nous redéfinissions les limites "normales" des valeurs cliniques et expérimentales courantes en relation avec les grands malades. Nous pouvons adopter une interprétation «contextuelle» des paramètres de la maladie et traiter les patients gravement malades en conséquence.

\section{Références}

(Voir page $\mathrm{Rl} 49$ ) 